\title{
PRINSIP DASAR PENDIDIKAN ANAK MENURUT PERSPEKTIF AL-QUR'AN
}

\author{
Rosdiana \\ Fakultas Tarbiyah dan Keguruan \\ UIN Alauddin Makassar
}

\begin{abstract}
:
The aims of children education in Al-Qur'an is a process of guiding from the tutor (parents or teachers) persistenty towards the physical, spritial, ad intelligence's children development to the formation of the good moslems. There are ten basic principles of children education need to be understood by all of the tutors in teaching based on Al-Qur'an perspective, namely: accepting the children in the way they are, as a child is a trust, educate the children according to capability, reminds that the main purpose of educating the children is in order to be liberated them from the Fire. The parents are required to strive but Allah SWT remains control the result. The parents are also required to be a good model for the children, to give the best advice, to educate not only their physical but also their spiritual, to educate the children according to their natural tendencies and do not stop it until apart. Allah SWT creates human and give a proper guidance in Al-Qur'an about the way to educate. If every tutors take Al-Qur'an as their guidance in educating the children, then they will bear the best intelligent generation with a good behavior and having a good social capacity based on the sincerely dedication to Allah SWT.
\end{abstract}

Keywords: Principlee, Educating children, Al-Qur'an Perspective

\section{PENDAHULUAN}

\section{Latar Belakang}

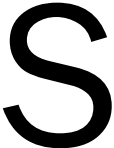
etiap orang tua pastilah mempunyai keinginan yang sama yaitu memiliki anak yang tumbuh dengan sehat, lucu, cerdas, mengukir segudang prestasi dan berbagai harapan serta keinginan yang baik untuk anaknya. Berbagai upaya dilakukan orang tua guna mewujudkan keinginan tersebut, namun tidak jarang ditemui semasa anak masih kecil sehat dan lucu, berubah menjadi sumber permasalahan. Begitu banyak fenomena memprihatinkan terjadi dimasyarakat yang tidak sepantasnya dilakukan oleh anak. Seorang anak berani melawan orang tua, menyiksa bahkan sampai membunuh orang tuanya. Bukan hanya itu saja, minum-minuman keras, konsumsi narkoba, tawuran, nonton video porno, bahkan melakukan pergaulan bebas sampai kepada hubungan seks pranikah yang akibatnya terjadi kehamilan dan aborsi, semua itu telah menjadi konsumsi berita yang dapat diketahui lewat pemberitaan di televisi, media cetak dan media sosial.

Upaya dari para praktisi pendidikan untuk selalu menyempurnakan sistem kurikulum pendidikan, tetapi hasilnya tidak sesuai dengan harapan. Kondisi ini lebih diperparah dengan pendidikan yang hanya konsentrasi dari sisi formal dan 
mengabaikan sisi moralnya. Akibatnya banyak orang tua, guru sekolah dan masyarakat luas merasakan dampaknya. Orang tua resah dengan keadaan anaknya yang suka berbohong, acuh tak acuh dan tidak mau membantu pekerjaan rumah. Guru sekolah gundah dengan sikap serta ulah muridnya, mulai dari masalah rambut, merokok, berkelahi, sering bolos, tidak disiplin dan lain-lain. Masyarakat luas kurang merasa aman karena banyaknya kasus kebut-kebutan dijalan, perkelahian antar kelompok, antar sekolah, demikian pula kriminalitas seperti mengancam, mengintimidasi, melakukan pembunuhan, mabuk-mabukan, homoseksual, perkosaan, pencurian dan lain-lain. Seluruh masalah kenakalan anak serta akibatnya merupakan masalah moral yang berakibat pada keluarga, masyarakat, bangsa dan negara. Adanya fenomena diatas merupakan indikasi bahwa pendidikan di keluarga, lembaga pendidikan formal maupun pendidikan non formal dan informal, diharapkan mampu untuk mengajarkan nilai-nilai moral sehingga anak memiliki budi pekerti yang baik, ramah, sopan, santun, rendah hati, suka menolong, solidaritas serta mampu berinteraksi dengan sesama.

Setiap anak dilahirkan dalam keadaan fitrah. Qalbunya yang masih suci seperti permata yang polos, bebas dari pahatan dan gambaran, siap untuk menerima pahatan apapun yang menjadi kecenderungan dan kebiasaan yang diberikan kepadanya.

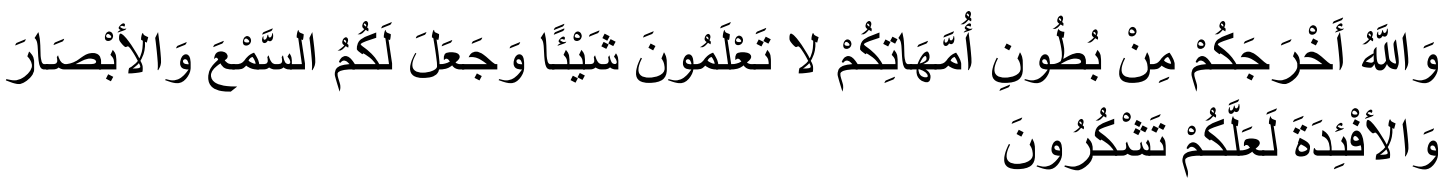

"Dan Allah mengeluarkan kamu dari perut ibumu dalam keadaan tidak mengetahui sesuatu pun, dan Dia memberi kamu pendengaran, penglihatan dan hati, agar kamu bersyukur" (Q.S. An Nahl: 78).

Semua manusia saat terlahir dalam keadaan tidak mengetahui sesuatu apapun, kemudian Allah memberikan pendengaran, penglihatan dan hati sebagai potensi dan kemampuan untuk menyerap pengetahuan. Dengan bekal tersebut, manusia dapat belajar dengan menggunakan panca indranya sebagai jendela pengetahuan, selanjutnya bertahap dari yang dapat dilihat kepada yang dapat dipahami, kemudian memasuki proses belajar melalui interaksi dengan lingkungannya. Sebagai mana sabda Rasulullah;

Artinya: "Setiap anak dilahirkan dalam keadaan fitrah, maka kedua ibu dan bapaknya lah yang membuatnya menjadi Yahudi, Majusi atau Nasrani" (al-Bukhari, 2001:92).

Sabda Rasulullah tersebut lebih memperkuat akan pentingnya pendidikan dan lingkungan untuk anak. Pendidikan pada anak merupakan upaya mewariskan nilai yang akan menjadi penuntun dan penolong menjalani kehidupan anak dan sekaligus untuk memperbaiki peradaban manusia. 
Menurut Kartikanita Widyasari seorang Pedongen Praktisi Psikologi, didalam seminar Parenting yaitu Rahasia menjadi orang Tua yang Responif dan menyenangkan adalah Orang tua ditutut harus selalu mewujudkan kasih sayang dan kehangatan, selalu bercanda, jangan berambisi untuk sempurna, nikmati peran sebagai orang tua.

Mendidik anak merupakan tanggung jawab orang tua yang tidak ringan. Orang tua harus menjadi guru sekaligus pembimbing dan pendidik. Berkenaan dengan hal tersebut, Quraish Shihab (2007:93) menyatakan bahwa Al-Qur'an sebagai kitab pendidikan dengan alasan hampir semua unsur pendidikan baik secara tersurat maupun tersirat didalamnya. Oleh karenanya Al-Qur'an telah menyebutkan cara-cara mendidik anak dengan baik dan benar yang dapat dijadikan pedoman bagi orang tua jika ingin anak-anak yang berkualitas untuk menuju generasi yang dicintai dan dibanggakan orang tua dan masyarakat.

\section{Rumusan Masalah}

Berdasarkan latar belakang di atas, penulis dapat merumuskan bahwa yang menjadi pokok permasalahan adalah "bagaimana prinsip-prinsip dasar pendidikan anak dalam perspektif Al-Qur'an" dengan membatasi sub-sub bahasan sebagai berikut:

1. Bagaimana hakekat pendidikan anak dalam Al-Qur'an?

2. Bagaimana prinsip-prinsip dasar pendidikan anak dalam perspektif Al-Qur'an?

\section{PEMBAHASAN}

\section{Hakekat Pendidikan Anak dalam Al-Qur'an}

Al-Qur'an merupakan pedoman hidup ummat Islam (QS. Al-Baqarah: 185). Bagi ummat Islam Al-Qur'an adalah kitab suci yang diyakini kebenarannya dan berfungsi sebagai petunjuk bagi siapa saja yang ingin mendapatkan kebahagiaan di dunia dan akhirat. Salah satu petunjuk Al-Qur'an yang sangat penting adalah dalam bidang pendidikan yang sarat dengan nilai-nilai kebaikan, karena Al-Qur'an itu sendiri merupakan sumber nilai.

Pendidikan merupakan bagian terpenting dalam kehidupan. Posisinya sangat strategis dalam membentuk budaya dan peradaban ummat manusia. Pada hakekatnya pendidikan merupakan upaya untuk menghantarkan dan membantu manusia menuju kearah kedewasaan. Pendidikan menurut UU No. 2 Tahun 1989, adalah usaha sadar untuk menyiapkan peserta didik melalui kegiatan bimbingan, pengajaran atau latihan bagi perannya dimana datang (Departemen Agama RI, 1992:3). Sedangkan pendidikan yang sesuai dengan ajaran Islam adalah suatu proses bimbingan dari pendidik sesuai dengan Al-Qur'an dan Sunnah serta mengikuti contoh yang telah dipraktekkan oleh Rasulullah dalam mendidik generasi terbaik. 
ROSDIANA

Pendidikan dalam bahasa arab dikenal dengan nama tarbiyah dan ta'dib. Tarbiyah di ambil dari akar kata raba- yarbu, yang berarti bertambah, tumbuh dan berkembang. Akar kata yang lain adalah rabba-yurabbi yang bermakna mendidik, mengajari dan mengasuh (Ali dan Mudhlor, 2003:952). Tarbiyah juga dapat diambil dari akar kata rabba-yarubbu yang berarti melindungi, menyantuni, mendidik dari aspek fisik, moral dan menjadikannya profesional (Anis, 1972:321). Lafaz tarbiyah dalam Al-Qur'an terulang sebanyak 2 kali dalam Al-Qur'an ada yang dalam bentuk fi'il madhi pada surah al-isra' ayat 24 dan ada pula dalam bentuk fi'il mudhari pada surah as-syua'ara ayat 18.

Adapun ta'dib merupakan masdar dari kata addaba yang berarti pendidikan yang seakar kata dengan kata adab yang berarti pengenalan dan pengakuan tentang hakikat. Dalam Al-Qur'an terulang sebanyak 41 kali yang semakna dengan kata ta'lim, tersebar dalam 18 surah

Kata lain selain tarbiyah dan ta'dib adalah tadris yang merupakan masdar dari kata darrasa yang berarti mempelajari dengan mendalam, menggali, meneliti, membahas dan mendiskusikan, juga dapat dimaknai pengajaran, pengarahan dan pendidikan (Atabik, 2003:890). Tadris dalam Al-Qur'an berulang sebanyak 6 kali, yang tersebar dalam 5 surah.

Dari penjelasan di atas, dapat menyimpulkan bahwa pendidikan dalam AlQur'an adalah upaya terus menerus yang dilakukan secara sadar oleh pendidik dalam mendidik anak berdasarkan ajaran Allah SWT yang terdapat dalam AI-Qur'an sehingga terbentuk anak yang berakhlak mulia, cerdas dan taat dalam ibadah.

Kata anak dalam bahasa arab semakna dengan kata ath-thifl yang bentuk jamaknya adalah athfaal. Dalam ensiklopedia anak, Abu Abdillah Ahmad bin Ahmad Al-Isawi menukil pendapat para ulama berkaitan dengan kata ath-thifl; Abul Haitsam berkata, "seorang anak disebut thifl sejak ia lahir dari kandungan ibunya hingga ia baligh". Dalam Kitab An-Nihayah (III/30); "thifl adalah anak kecil yang berkelamin laki-laki maupun perempuan. Boleh juga dikatakan thifl untuk anak laki-laki dan thiflah untuk anak perempuan". Yang dimaksud dengan kata thifl disini adalah seorang anak sejak ia lahir hingga mencapai usia dewasa (Al-lsawi, 2008:58-59).

Berdasarkan makna pendidikan serta pembacaan mendalam menyangkut anak, penulis dapat menyimpulkan bahwa hakekat pendidikan anak dalam AlQur'an adalah suatu proses bimbingan dari pendidik (orang tua dan atau guru) terhadap perkembangan jasmani, rohani dan akal peserta didik (anak) kearah terbentuknya pribadi muslim yang baik.

\section{Prinsip Dasar Pendidikan Anak dalam Perspektip Al-Qur'an}

Dalam Kamus Besar Bahasa Indonesia, prinsip adalah asas kebenaran yang menjadi pokok berfikir, bertindak dan sebagainya. Dalam pengertian bebas, wikipedia menyebutkan defenisi prinsip adalah suatu pernyataan fundamental atau 
kebenaran umum maupun individual yang dijadikan oleh seseorang atau kelompok sebagai pedoman untuk berfikir dan bertindak.

Perspektif menurut J.S. Badudu dan Sutan Muhammad Zain, berasal dari bahasa Belanda, berarti: (1) sesuatu yang harus diperhatikan dalam membuat gambar; dan (2) pandangan jauh kemasa depan (Badudu dan Zain, 1994).

Jadi yang dimaksud dengan prinsip dasar pendidikan anak dalam perspektif Al-Qur'an adalah bagaimana pandangan AI-Qur'an tentang cara mendidik anak dengan menggunakan prinsip-prinsip dasar pendidikan anak yang terdapat dalam Al-Qur'an atau dengan kata lain bagaimana pendidikan anak menurut Al-Qur'an.

Dalam uraian sebelumnya bahwa AI-Qur'an adalah merupakan pedoman hidup yang mengatur seluruh kehidupan manusia, salah satunya adalah mengajarkan bagaimana cara mendidik anak. Adapun prinsip-prinsip dasar dalam pendidikan anak dalam Al-Qur'an yang seharusnya diketahui oleh setiap orang tua atau pendidik adalah sebagai berikut:

\section{Terimalah Anakmu Apa Adanya}

Anak yang lahir merupakan nikmat dari Allah. Kehadirannya didunia adalah merupakan karunia dari Allah bagi kedua orang tuanya. Namun hal yang perlu diperhatikan bagi orang tua adalah mampu menerima anak apa adanya. Prinsip ini cukup penting sebab anak yang lahir bukanlah pilihan dan kemauan orang tua, begitu pula anak bukan karena keinginan mereka, tetapi semua itu karena takdir Allah. Firman Allah dalam surah al-qashas ayat 68 berbunyi:
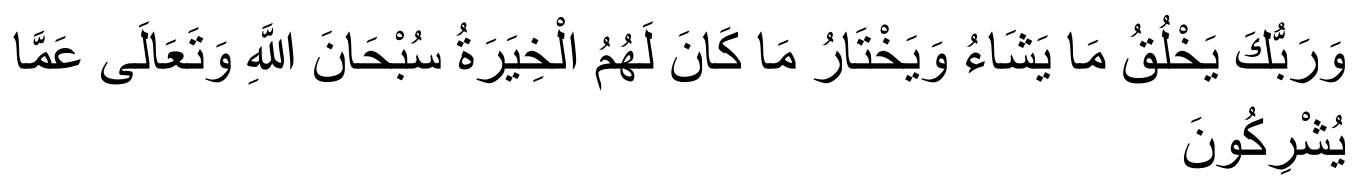

Artinya:

“Dan Tuhanmu menciptakan apa yang Dia kehendaki dan memilihnya. Sekali-kali tidak ada pilihan bagi mereka. Maha Suci Allah dan Maha Tinggi dari apa yang mereka persekutukan (dengan Dia)."

Ayat di atas mengatakan bahwa hanya Allah Swt yang mencipta dan berkehendak apapun yang la ciptakan. Adapun ayat yang lebih mempertegas lagi tentang hal tersebut adalah terdapat dalam surah Asy-syura ayat 49 dan 50 yang berbunyi:

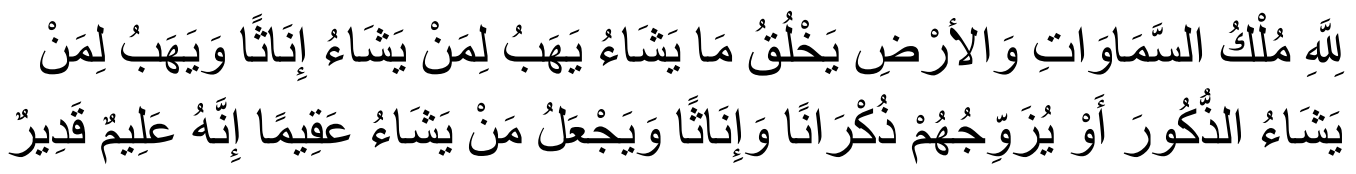

Artinya:

“Kepunyaan Allah-lah kerajaan langit dan bumi, Dia menciptakan apa yang Dia kehendaki, Dia memberikan anak-anak perempuan kepada siapa yang Dia kehendaki dan memberikan anak-anak lelaki kepada siapa yang Dia kehendaki, atau Dia menganugerahkan kedua jenis laki-laki dan perempuan (kepada siapa 
yang dikehendaki-Nya), dan Dia menjadikan mandul siapa yang Dia kehendaki. Sesungguhnya Dia Maha Mengetahui lagi Maha Kuasa"

Prinsip ini penting, sebab terkadang ada orang tua yang menginginkan anak yang lahir adalah perempuan, namun kenyataannya adalah laki-laki, sehingga, menimbulkan kekecewaan. Efeknya cukup berat bagi anak, sebab dengan kekecewaan tersebut akan membuat anak menjadi minder, kurang percaya diri, merasa diri tidak berharga dan berbagai efek psikologis lainnya. Jika orang tua mau menerima anak yang lahir itu apa adanya sekalipun anak yang terlahir dalam keadaan cacat, maka anak akan bangga sebagai anak, dan kehadirannya di atas permukaan bumi ini terasa berharga.

Dalam dunia pendidikan prinsip ini penting juga diketahui, sebab setiap anak terlahir dengan rezeki dan kemampuan yang berbeda-beda. Kebiasaan pendidik hanya mau menerima anak didik yang pintar dari sisi kognitip, seperti kecerdasan matematis-logis yang ditandai dengan nilainya selalu baik sebagai anak pintar. Adapun untuk anak yang tidak mempunyai kecerdasan dari sisi kognitip, dianggap sebagai anak yang bodoh dan sulit untuk berkembang. Padahal para pakar ilmu jiwa dan pendidikan, diantaranya adalah Howar Gardner telah menemukan delapan peta kecerdasan yang masing-masing manusia pasti mempunyai satu atau lebih dari kecerdasan tersebut. Peta kecerdasan itu adalah sebagai berikut:

a. Spasial-visual, berfikir dalam citra dan gambar. Melibatkan kemampuan untuk memahami hubungan ruang dan citra mental, seperti menggambar, mensketsa, visualisasi, grafik, seni, film, ilustrasi dan lain-lain

b. Linguistik-verbal, yaitu cerdas dalam kata-kata. Mencakup kemahiran berbahasa untuk berbicara, menulis, membaca, bercerita, pidato, menafsirkan.

c. Interpersonal, yaitu cerdas dalam berkomunikasi dengan orang lain. Mencakup kemahiran berkomunikasi dan berinteraksi dengan orang lain, seperti kecakapan berorganisasi, memimpin, berbicara, bersosialisasi, pendamai, berbagi.

d. Musikal-ritmik, yaitu kecerdasan musikal, seperti penikmat musik, penyanyi, komposer, mengetahui warna nada.

e. Naturalis, yaitu kecerdasan acuan alam. Mencakup pertalian seseorang dengan alam, seperti pecinta alam, berinteraksi dengan hewan, pecinta tanaman.

f. Body-kinestetik, yaitu kecerdasan sensasi dan gerakan fisik. Kemampuan untuk mengendalikan dan menggunakan fisik dengan mudah dan cekatan. Seperti penari, atlet, pemain drama, pematun.

g. Intrapersonal, yaitu cerdas reflektif. Mengacu pada kesadaran reflektif mengenai perasaan dan proses pemikiran diri sendiri, seperti pemikir, meditasi, membuat jurnal, menulis buku. 
h. Logis-matematis, yaitu cerdas dengan penalaran. Melibatkan pemecahan masalah secara logis dan ilmiah serta kemampuan matematis. Seperti, akuntan dan ahli matematika (DePorter, Reardon dan Nourie, 2002:97-98).

Jika para pendidik memahami bahwa setiap anak memiliki kecerdasannya masing-masing, maka mereka akan menerima anak didiknya apa adanya, serta melejitkan potensinya sesuai dengan kecerdasan yang dimiliki.

\section{Anak Merupakan Amanah}

Anak adalah amanah dari Allah untuk orang tua. Apa yang telah ditakdirkan Allah, itulah amanah yang harus ditunaikan. Perintah untuk menjaga amanah terdapat dalam surah al-anfal ayat 27 dan 28:

artinya:

“Hai orang-orang yang beriman, janganlah kamu mengkhianati Allah dan Rasul (Muhammad) dan (juga) janganlah kamu mengkhianati amanat-amanah yang dipercayakan kepadamu, sedang kamu mengetahui. Dan ketahuilah, bahwa hartamu dan anak-anakmu itu hanyalah sebagai cobaan dan sesungguhnya di sisi Allah-lah pahala yang besar".

Pendidikan yang terbaik adalah merupkan hak anak dan kewajiban orang tua. Tanggung jawab terhadap anak bukan hanya sekedar memberinya makan kenyang, pakaian bagus ataupun rumah yang lapang. Tanggung jawab yang lebih berat adalah memberikan pendidikan terbaik bagi mereka dan selamat dari azab neraka. Allah memerintahkan agar orang tua mendidik anaknya dengan sebaik-baiknya, dalam surah at-tahrim ayat 6 disebutkan yang artinya:

"Hai orang-orang yang beriman, peliharalah dirimu dan keluargamu dari api neraka yang bahan bakarnya adalah manusia dan batu; penjaganya malaikat-malaikat yang kasar, yang keras, yang tidak mendurhakai Allah terhadap apa yang diperintahkan-Nya kepada mereka dan selalu mengerjakan apa yang diperintahkan"

Berkenaan dengan ayat tersebut, Ali bin Abi Thalib berkata, "yakni ajarilah dirimu dan keluargamu nilai-nilai kebaikan". Setiap amanah pasti akan dimintai pertanggung jawabannya, sebagaimana Rasulullah bersabda yang artinya:

"Kamu semua adalah pemimpin dan kamu akan ditanya tentang apa yang dipimpinnya. Seorang lelaki adalah pemimpin atas keluarganya dan ia akan ditanya tentang mereka. Seorang wanita adalah pemimpin dalam rumah suami dan anak-anaknya, dan ia akan ditanyai tentang mereka. Ketahuilah, kamu semua adalah pemimpim dan kamu akan ditanya tentang apa yang kamu pimpin" (Riwayat Al-Bukhari:893 dan Muslim:4828.

Maka jagalah amanah dengan baik sebab Allah menjanjikan balasan pahala yang besar bagi orang-orang yang senantiasa memelihara amanah yang dipikulnya. 
Merekalah orang-orang yang berhak mewarisi surga Firdaus dan mereka akan kekal didalamnya. Allah berfirman di surah al-mukminun ayat 8, 10 dan 11, yang artinya:

"Dan orang-orang yang memelihara amanat-amanat (yang dipikulnya) dan janjinya, Mereka itulah orang-orang yang akan mewarisi, (yakni) yang akan mewarisi surga Firdaus. Mereka kekal di dalamnya".

Amanah mendidik anak tidaklah ringan. Melaksanakan tanggung jawab ini tidak semudah membalikkan telapak tangan. Ujian dan rintangan akan silih berganti, namun jika tanggung jawab ini dilaksanakan dengan penuh ke ikhlasan, niscaya akan membawa kebaikan. Sebab seberat apapun tugas dan tanggung jawab, bila dilakukan dengan penuh kerelaan, kegembiraan dan harapan, maka tugas seberat apapun akan terasa ringan. Lebih dari itu, ke ikhlasan akan merubah jerih payah menjadi pahala yang sangat besar serta ampunan.

\section{Didiklah Anak Sesuai dengan Kesanggupan}

Keinginan mempunyai anak merupakan janji kepada Allah, maka tepatilah janji tersebut dengan mendidik anak sebaik-baiknya, karena setiap janji akan dimintai pertanggung jawaban (lihat surah al-maidah ayat 1, surah al-isra' ayat 34 dan surah ar-raad ayat 19-24).

Namun dalam melaksanakan tanggung jawab tersebut, setiap orang tua harus sesuai dengan kemampuan, jangan memaksakan diri apalagi sampai menyiksa diri, Sebab Allah tidak membebani orang tua dalam mendidik anaknya melampaui kemampuan yang dimiliki, maka bersungguh-sungguhlah.

\section{Didiklah Anakmu Agar Terbebas dari Neraka}

Allah tidak mewajibkan orang tua untuk membentuk anak mahir dalam segala hal, namun yang Allah wajibkan bagi setiap orang tua adalah membentuk anaknya menjadi anak yang shaleh dan terbebas dari azab api neraka. Diantara ayat yang berhubungan dengan hal ini adalah:

a. Mendoakannya dengan sungguh-sungguh baik sebelum maupun sesudah lahir.

1) Surah Ash-Shaffat ayat 100:

"Ya Tuhanku, anugerahkanlah kepadaku (seorang anak) yang termasuk orang-orang yang saleh".

2) Surah Ibrahim ayat 40:

"Ya Tuhanku, jadikanlah aku dan anak cucuku orang-orang yang tetap mendirikan salat, ya Tuhan kami, perkenankanlah doaku"

b. Mendidiknya dengan sungguh-sungguh dan sepenuh hati.

Surah At-Tahrim Ayat 6:

"Hai orang-orang yang beriman, peliharalah dirimu dan keluargamu dari api neraka yang bahan bakarnya adalah manusia dan batu; penjaganya malaikatmalaikat yang kasar, yang keras, yang tidak mendurhakai Allah terhadap apa 
yang diperintahkan-Nya kepada mereka dan selalu mengerjakan apa yang diperintahkan"

Jadi upaya mendidik anak adalah merupakan usaha yang sungguh-sungguh. Dengan pemahaman bahwa setiap anak terlahir dengan reseki dan kelebihan masing-masing, orang tua tidaklah dituntut untuk menjadikan anaknya seperti apa yang dikehendaki orang tua, namun hanya mengarahkan sesuai dengan bakat dan minat anak. Hal yang wajib dilakukan orang tua dalam pendidikan anak mereka adalah mendidik anak sedini mungkin untuk menjadi anak yang shaleh, dan yang menjadi puncak harapan orang tua adalah agar supaya semua anak dan keluarganya terbebas dari neraka. Prinsip ini sangat penting, sebab dengan keshalehan anak, menjadi apapun anak tersebut kedepannya maka ia tetap akan menjadi pribadi yang baik, taat beribadah kepada Allah serta berkarakter unggul.

\section{Orang Tua Hanya Dituntut untuk Berusaha dan yang Menentukan Segalanya adalah Allah SWT.}

Upaya untuk mendidik anak adalah kewajiban yang dibebankan kepada orang tua, adapun hasil dari upaya tersebut mutlak adalah dalam ketentuan Allah. Diantara ayat yang menjelaskan tentang hal tersebut adalah:

Surah Al-A'raf ayat 178:

"Barang siapa yang diberi petunjuk oleh Allah, maka dialah yang mendapat petunjuk; dan barang siapa yang disesatkan Allah, maka merekalah orang-orang yang merugi"

Surah Fathir ayat 8:

"maka sesungguhnya Allah menyesatkan siapa yang dikehendaki-Nya dan menunjuki siapa yang dikehendaki-Nya; maka janganlah dirimu binasa karena kesedihan terhadap mereka. Sesungguhnya Allah Maha Mengetahui apa yang mereka perbuat"

\section{Jadilah Teladan yang Baik dihadapan Anak}

Setiap anak dilahirkan dalam keadaan fitrah Sebagai mana sabda Rasulullah; Artinya: "Setiap anak dilahirkan dalam keadaan fitrah, maka kedua ibu dan bapaknya lah yang membuatnya menjadi Yahudi, Majusi atau Nasrani”.

Imam Ghazali berpendapat: “anak adalah amanah di tangan kedua orang tuanya. Hatinya yang suci adalah mutiara yang masih mentah, belum dipahat maupun dibentuk. Mutira ini dapat dipahat dalam bentuk apapun, mudah condong kepada segala sesuatu. Apabila dibiasakan dan diajari dengan kebaikan, maka dia akan tumbuh dalamkebaikan itu. Dampaknya, kedua orang tuanya akan hidup berbahagia di dunia dan akhirat. Semua orang dapat menjadi guru dan pendidiknya. Namun apabila dibiasakan dengan keburukan dan dilalaikan, pasti sianak akan celaka dan binasa. Dosanya akan melilit leher orang yang seharusnya bertanggung jawab atasnya dan menjadi walinya" (Suwaid, 2010:46). 
ROSDIANA

Disinilah pentingnya keteladanan orang tua dalam mendidik anak-anaknya. Anak yang lahir dalam keadaan fitrah, ibarat mutiara yang siap di pahat atau diukir apa saja, ibarat kertas putih yang siap ditorehkan kalimat apa saja diatasnya. Berkenaan dengan hal tersebut, dalam Al-Qur'an surah an-nahl ayat 78 disebutkan:

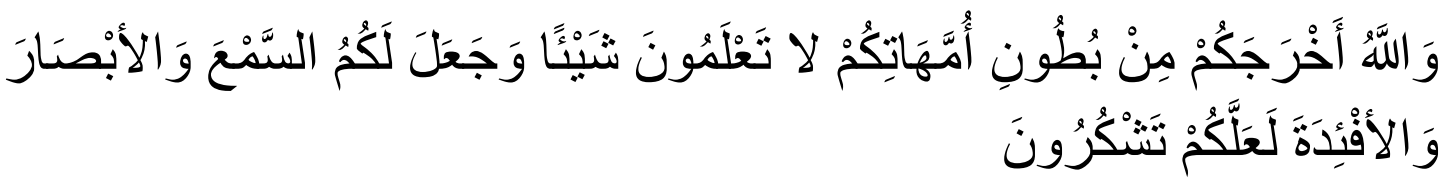

Artinya: "Dan Allah mengeluarkan kamu dari perut ibumu dalam keadaan tidak mengetahui sesuatu pun, dan Dia memberi kamu pendengaran, penglihatan dan hati, agar kamu bersyukur".

Dalam ayat ini disebutkan bahwa semua anak yang lahir dalam kondisi tidak mengetahui apa-apa, otaknya seperti komputer yang berkapasitas tinggi namun belum berisi file-file. Kemudian Allah memberikan sumber penyerap informasi dan ilmu pengetahuan untuk otak tersebut yaitu pendengaran, penglihatan dan hati. Dengan ketiga nikmat tersebut maka anak akan mudah untuk belajar dari apa yang ia dengar, lihat dan rasakan. Ibarat spon yang mampu menyerap air, maka demikian pulalah otak anak akan dengan mudah menyerap informasi apapun yang ada disekitarnya. Disinilah peran orang tua sebagai pemberi informasi dan ilmu pengetahuan untuk anak. Maka pantas apabila Rasulullah menyebutkan bahwa orang tuanyalah yang menyebabkan anak itu sesuai dengan fitrahnya (Islam) atau menjadikan anaknya menjadi Yahudi, Majusi atau Nasrani. Cetak biru anak tersebut tergantung dari orang tuanya, oleh karena itu ayah dan ibu adalah dua unsur penting bagi anaknya. Jika orang tua berharap agar anaknya menjadi anak yang shaleh, maka yang lebih shaleh terlebih dahulu adalah kedua orang tuanya, demikian pula sebaliknya.

Keteladanan orang tua mempersyaratkan satunya kata dan perbuatan. Begitulah kata pepatah, "seribu kata-kata tak akan berarti dengan satu tindakan yang bertentanagan dengan kata-kata itu". Demikian pentingnya hal tersebut, Allah berfirman dalam surah ash-shaff ayat 2 dan 3:

Artinya:

"Hai orang-orang yang beriman, mengapa kamu mengatakan apa yang tidak kamu perbuat? Amat besar kebencian di sisi Allah bahwa kamu mengatakan apa-apa yang tiada kamu kerjakan"

Ada beberapa hal menyangkut dengan keteladanan yang perlu diperhatikan oleh orang tua dalam mendidik anak-anaknya:

a. Jangan pernah berharap kebaikan dari anak-anakmu, bila engkau tidak mendidik mereka menjadi anak-anak yang shaleh (lihat Al-Qur'an surah maryam ayat 59; surah hud ayat 46)

b. Jangan pernah berharap banyak pada anak-anakmu bila engkau tidak mendidik mereka sebagai mana mestinya (lihat Al-Qur'an surah al-isra ayat 24) 
c. Jangan berharap anak-anakmu sebagai anak yang shaleh sebelum engkau menjadi shaleh terlebih dahulu (lihat Al-Qur'an surah ash-shaff ayat 2-3; surah al-baqarah ayat 44; surah at-tahrim ayat 6)

d. Janganlah menuntut hak-hakmu dari anak-anakmu sebelum engkau memberi hak anak-anakmu (lihat Al-Qur'an surah lukaman ayat 12 sd 19)

e. Janganlah engkau menuntut hak-hakmu dari anak-anakmu, sampai engkau memenuhi hak-hak Allah atasmu (lihat Al-Qur'an surah al-baqarah ayat 83, surah annisa ayat 36; surah al-an'am ayat 151; surah al-isra' ayat 23-24).

\section{Bimbingan dan Nasehat}

Prinsip utama dalam pendidikan anak adalah pemberian nasehat. Nasehat adalah merupakan sarana yang dapat menghubungkan jiwa seseorang dengan cepat. Apabila nasehat yang diucapkan pendidik dikeluarkan dengan tulus dan penuh rasa kasih sayang, niscaya akan memberikan pengaruh yang langsung menghunjam ke dalam hati anak. Sebab jiwa anak akan terpengaruh dengan katakata yanag disampaikan kepadanya, apalagi jika kata-kata tersebut dihiai dengan keindahan, kelembutan dan kasih sayang.

Jangan pernah seorang pendidik merasa bosan untuk memberikan nasehat kepada anak didiknya, sebab sekecil apapun nasehat yang diberikan maka pasti akan berbekas pada diri anak. Banyak sekali ayat didalam Al-Qur'an yang menerangkan tentang nasehat yang baik, diantaranya adalah:

a. Al-Qur'an Surah al-Baqarah ayat 83:

Artinya: “...serta ucapkanlah kata-kata yang baik kepada manusia, dirikanlah salat..."

b. Al-Qur'an Surah An-Nahl ayat 125:

Artinya: "Serulah (manusia) kepada jalan Tuhanmu dengan hikmah dan pelajaran yang baik dan bantahlah mereka dengan cara yang baik. Sesungguhnya Tuhanmu Dialah yang lebih mengetahui tentang siapa yang tersesat dari jalan-Nya dan Dialah yang lebih mengetahui orang-orang yang mendapat petunjuk."

c. Al-Qur'an Surah Thaha ayat 44:

Artinya: "maka berbicaralah kamu berdua kepadanya dengan kata-kata yang lemah lembut, mudah-mudahan ia ingat atau takut".

Dalam hal pemberian nasehat, Al-Qur'an telah memberikan contoh terbaik yaitu lewat kisah Lukman disaat memberikan nasehat kepada anaknya. Kisahnya diabadikan dalam surah lukman ayat 12 sd ayat 19. Sayyid Qutub dalam Fi Dzilalil Qur'an nya (Abdulmuqtadir, 2008:38) menyebutkan "nasehat yang disampaikan Lukman kepada anaknya adalah nasehat bijak. Nasehat yang membebaskan dari aib dan orang yang mengucapkannya dikaruniai hikmah. Nasehat yang tidak menuduh karena tidak mungkin seorang ayah menasehati anaknya dengan menuduh. Dalam menasehati seorang ayah hanya mengimginkan kebaikan pada 
anaknya dengan memberi nasehat padanya". Ada 10 nasehat agung yang disampaikan lukman kepada anaknya yang secara singkat disebutkan sebagai berikut:

1) Nasehat pertama: jangan menyekutukan Allah, Surah lukman ayat 13:

Artinya: "Dan (ingatlah) ketika Lukman berkata kepada anaknya, di waktu ia memberi pelajaran kepadanya: "Hai anakku, janganlah kamu mempersekutukan (Allah) sesungguhnya mempersekutukan (Allah) adalah benar-benar kelaliman yang besar"."

2) Nasehat kedua: berbakti kepada kedua orang tua, surah lukman ayat 14:

Artinya: "Dan Kami perintahkan kepada manusia (berbuat baik) kepada dua orang ibu-bapaknya; ibunya telah mengandungnya dalam keadaan lemah yang bertambah-tambah, dan menyapihnya dalam dua tahun. Bersyukurlah kepadaKu dan kepada dua orang ibu bapakmu, hanya kepada-Kulah kembalimu."

3) Nasehat ketiga: tidak ada ketaatan dalam mendurhakai Allah, surah lukman ayat 15

Artinya: "Dan jika keduanya memaksamu untuk mempersekutukan dengan Aku sesuatu yang tidak ada pengetahuanmu tentang itu, maka janganlah kamu mengikuti keduanya, dan pergaulilah keduanya di dunia dengan baik..."

4) Nasehat keempat: pentingnya merasa diri diawasi Allah (muraqabatullah) dan hari perhitungan amal, surah lukman ayat 16:

Artinya: "(Lukman berkata): "Hai anakku, sesungguhnya jika ada (sesuatu perbuatan) seberat biji sawi, dan berada dalam batu atau di langit atau di dalam bumi, niscaya Allah akan mendatangkannya (membalasinya). Sesungguhnya Allah Maha Halus lagi Maha Mengetahui."

5) Nasehat kelima: pentingnya mendirikan shalat, surah lukman ayat $17:$

Artinya: "Hai anakku, dirikanlah salat dan.... "

6) Nasehat keenam: amar ma'ruf nahi mungkar, surah lukman ayat 17:

Artinya: "suruhlah (manusia) mengerjakan yang baik dan cegahlah (mereka) dari perbuatan yang mungkar..."

7) Nasehat ketujuh: bersabarlah akan ujian yang menimpa, surah lukman ayat 17:

Artinya: “.... bersabarlah terhadap apa yang menimpa kamu. Sesungguhnya yang demikian itu termasuk hal-hal yang diwajibkan (oleh Allah)"

8) Nasehat kedelapan: jangan berlaku sombong, surah lukman ayat 18:

Artinya: "Dan janganlah kamu memalingkan mukamu dari manusia (karena sombong) ...."

9) Nasehat kesembilan: jangan berjalan dengan angkuh, surah lukman ayat 18: Artinya: “.... dan janganlah kamu berjalan di muka bumi dengan angkuh. Sesungguhnya Allah tidak menyukai orang-orang yang sombong lagi membanggakan diri". 
10) Nasehat kesepuluh: sederhana dalam berjalan serta bertutur kata yang baik, surah lukman ayat 19:

Artinya: "Dan sederhanalah kamu dalam berjalan dan lunakkanlah suaramu. Sesungguhnya seburuk-buruk suara ialah suara keledai”.

Kesepuluh nasehat berharga diatas adalah merupakan inti sari dari seluruh kebaikan yang mencakup aqidah, ibadah dan akhlak yang sangat penting diketahui oleh setiap pendidik dalam membimbing anak-anaknya agar menjadi anak yang berkarakter baik dalam kehidupannya.

\section{Didiklah jiwa anak}

Pendidikan dalam Islam bersifat integral dan selaras antara jasmani dan rohani. Tujuannya agar melahirkan insan yang shaleh, lurus, berakal sehat, berakhlak mulia serta selaras antara fisik dan jiwanya. Al-Qur'an sangat memperhatikan sis kejiwaan anak, hal ini terdapat dalam surah asy-syams ayat 7 sd 10:

Artinya: “dan jiwa serta penyempurnaannya (ciptaannya), maka Allah mengilhamkan kepada jiwa itu (jalan) kefasikan dan ketakwaannya, sesungguhnya beruntunglah orang yang menyucikan jiwa itu, dan sesungguhnya merugilah orang yang mengotorinya."

Berkenaan dengan hal tersebut, Mustafa Abu Sa'ad dalam bukunya Positive Parenting bahwa ada delapan alasan mengapa pendidkan kejiwaan penting untuk diberikan para pendidik terhadap anaknya, yaitu:

a. Pendidkan kejiwaan adalah mempersiapkan manusia secara kejiwaan dan perasaan untuk menjalankan tugas dalam kehidupan.

b. Pendidikan kejiwaan adalah menumbuhkan sifat-sifat baik dan positip seseorang, serta peningkatan menuju kesempurnaan sebisa mungkin.

c. Pendidikan kejiwaan adalah mengarahkan perilaku anak menuju pembangunan kepribadian yang lurus.

d. Pendidikan kejiwaan adalah menjaga fitrah manusia, berusaha untuk menjaga dan mengembangkannya.

e. Pendidikan kejiwaan adalah melatih anak untuk disiplin yang bisa membantu untuk mempersiapkan kemampuan dalam menjalankan kewajiban-kewajiban dengan baik.

f. Pendidikan kejiwaan adalam membangun orientasi jiwa anak seputar kehidupan, alam semesta, manusia dan tugasnya dalam kehidupan ini, juga membangun orientasi terhadap apa yang ada disekitar anak. Orientasi inilah yang membentuk penilaian dalam diri anak untuk mengetahui mana yang benar dan mana yang salah, baik dan buruk, mana yang diterima dan mana yang tidak. Dengan kata lain, membangun perasaan anak yang bisa membentuk pembeda dalam dirinya. 
g. Pendidikan kejiwaan adalah mengembangkan perhatian anakterhadap motivasi-motivasi diri yang akan membentuk kemammpuan dan dorongan untuk berbuat baik.

h. Pendidikan kejiwaan adalah mendidik dan mengatur segala instink dengan kaidah-kaidah Islam, namun bukan berarti mengekang ataupun kebebasan mutlak (Abu Saad, 2016:17-18).

\section{Didiklah Anak sesuai Fitrahnya}

Menyangkut tentang menjaga fitrah anak, Al-Qur'an menerangkan tentang hal tersebut dalam surah ar-ruum ayat 30:

Artinya: "Maka hadapkanlah wajahmu dengan lurus kepada agama (Allah); (tetaplah atas) fitrah Allah yang telah menciptakan manusia menurut fitrah itu. Tidak ada perubahan pada fitrah Allah. (Itulah) agama yang lurus; tetapi kebanyakan manusia tidak mengetahui".

Fitrah yang dimaksud dalam ayat ini adalah ketetapan Allah atau sunnatullah yang tak akan pernah berubah. Salah satu fitrah tersebut adalah dimana Allah telah menciptakan manusia dalam beberapa fase atau tahapan semenjak dalam rahim ibu, demikian pula pada saat lahir diatas permukaan bumi ini juga mengikuti fase perkembangan yang sama. Mulai dari bayi, anak-anak, remaja, dewasa sampai pada usia lanjut. Setiap fase mempunyai karakteristik, sehingga apabila orang tua memahami dengan baik karakter anak dalam tiap fase tersebut, maka akan dengan mudah orang tua membimbing anaknya sesuai dengan fitrah tersebut.

\section{Jangan Pernah Putus Asa dalam Mendidik anak}

Tugas dan tanggung jawab orang tua adalah mendidik anaknya. Orang tua jangan pernah berfikir tentang hasil akhir dari usahanya sebab yang menetukan semuanya adalah Allah. Oleh karena itu didiklah anak-anakmu dengan penuh kesungguhan, Allah berfirman di surah hud ayat 93:

Artinya: "Dan (dia berkata): "Hai kaumku, berbuatlah menurut kemampuanmu, sesungguhnya aku pun berbuat (pula). Kelak kamu akan mengetahui siapa yang akan ditimpa azab yang menghinakannya dan siapa yang berdusta. Dan tunggulah azab (Tuhan), sesungguhnya aku pun menunggu bersama kamu."”

Demikian pula janganlah pernah berhenti dalam mendidik mereka sampai dengan kematian memisahkan. Allah berfirman dalam surah al-hijr ayat 99:

Artinya: "dan sembahlah Tuhanmu sampai datang kepadamu yang diyakini (ajal).".

Dari sepuluh prinsip dasar pendidikan anak dalam perspektif Al-Qur'an, bahwa Allah yang menciptakan manusia dan telah memberikan petunjuk yang sangat jelas dalam Al-Qur'an tentang cara mendidik manusia. Jika setiap pendidik menjadikan Al-Qur'an sebagai pedomannya dalam mendidik anak, maka akan lahirlah generasi-generasi terbaik yang cerdas, berakhlak mulia serta memiliki 
kapasitas sosial yang baik yang dilandasi pengabdian yang tulus hanya kepada Allah.

\section{PENUTUP}

\section{Kesimpulan}

Berdasarkann pembahasan sebelumnya sehingga diperoleh kesimpulan sebagai berikut:

1. Dasar pendidikan anak dalam Al-Qur'an adalah suatu proses bimbingan dari pendidik (orang tua atau guru) secara terus menerus terhadap perkembangan jasmani, rohani dan akal peserta didik (anak) kearah terbentuknya pribadi muslim yang baik.

2. Ada sepuluh prinsip dasar pendidikan anak yang perlu dipahami oleh para pendidik dalam mendidik berdasarkan perspektif Al-Qur'an, yaitu: terimalah anak apa adanya, anak adalah amanah, didiklah anak sesuai dengan kesanggupan, tujuan utama mendidik anak adalah agar terbebas dari neraka, orang tua hanya dituntut untuk berusaha sedang yang menentukan semuanya adalah Allah, jadilah teladan yang baik dihadapan anak, selalulah memberi nasehat, didiklah jiwanya selain jasmaninya, didiklah sesuai dengan fitrahnya dan teruslah mendidiknya tanpa jemu sampai dengan ajal menjemput. Allah lah yang menciptakan manusia dan telah memberikan petunjuk yang sangat jelas dalam Al-Qur'an tentang cara mendidik manusia. Jika setiap pendidik menjadikan Al-Qur'an sebagai pedomannya dalam mendidik anak, maka akan lahirlah generasi-generasi terbaik yang cerdas, berakhlak mulia serta memiliki kapasitas sosial yang baik yang dilandasi pengabdian yang tulus hanya kepada Allah SWT.

\section{Implikasi}

Mencermati pembahasan tentang prinsip dasar pendidikan anak dalam perspektif Al-Qur'an, maka dapat dikemukakan buah pemikiran bahwa untuk mendidik anak tidak ada jalan lain kecuali kembali kepada Al-Qur'an, sebab AlQur'an adalah merupakan pedoman hidup termasuk pedoman dalam mendidik anak, sehingga setiap pendidik dituntut untuk lebih mendalami Kitab Suci AlQur'an.

\section{DAFTAR PUSTAKA}

Abu Sa'ad, Mustafa. Positive Paenting Aplikasi Pola Asuh Anak yang Baik untuk Mewujudkan Generasi Shalih. Solo: Kiswah Media, 2016.

Adawi, Musthofa. Tarbiyatul Abna' Bagaimana Nabi Mendidik Anak. Jogjakarta: Pustaka Al Haura', 2002. 
ROSDIANA

Amin Suma, Muhammad. Ulumul Qur'an. Jakarta: Rajawali Pers, 2013.

Ahmad al Isawi, abu Abdillah Ahmad. Ensiklopedia Anak, Tanya Jawab Anak Dari A Sampai Z. Jakarta: Darus Sunnah Press, 2008.

Anis, Ibrahim. Al-Mu'jam Al-Wasit. Istambul: Al-Maktabah Al-Islamiyah, 1972.

Al Farmawi, Abd Al Hayy. Bidaya Fit Al Tafsir Al-Maudhu'i. Kairo: Hadrat AlGharbiyah, 1977.

Al-Bukhari, Ibn Ismai Muhammad. Shahih Al-Bukhari, Beirut: Dar Al-Kutub AlIImiyah, 2001 juz I

Al-Qur'an Al-Karim

Al-Qur'an Digital, Versi 2.1, 2004.

Atabik Ali dan Ahmad Zuhdi. Kamus Kontemporer Arab-Indonesia. Yogyakarta: Multi Karya Grafika Pondok Pesantren Krapyak, cet VIII. 2003.

Bobbi DePorter, Mark Reardon dan Sarah Singer-Nourie. Quantum Teaching Mempraktekkan Quantum Learing di Ruang-Ruang Kelas Teaching. Bandung: Penerbit Kaifa, 2002.

Deprtemen Agama, RI. Himpunan Perundang-Undangan Sistem Pendidikan Nasional. Jakarta: Dirjen Bimbingan Islam, cet VII. 2003.

Departemen Pendidikan dan Kebudayaan. Kamus Besar Bahasa Indonesia. Jakarta: Balai Pustaka

Hafizh Suwaid, Muhammad Nur. Prophetic Parenting Cara Nabi Mendidik Anak. Yogyakarta: Pro-U Media, 2010.

https://id.m.wikipedia.org. Prinsip-wikipedia bahasa indonesia, ensiklopedia bebas, diakses hari rabu pukul 20:04.

J.S. Badudu dan Sutan Muhammad Zain. Kamus Umum Bahasa Indonesia. Jakarta: Pustaka Sinar Harapan, 1994.

Khaeruman, Badri. Sejarah Perkembangan Tafsir Al-Qur'an. Bandung: Pustaka Setia, 2004.

Muqtadir, Ibrahim Abdul. Wisdom of Luqman El-Hakim, 12 Cara Membentengi Kerusakan Akhlak. Solo: Aqwam Jembatan IImu, 2008.

Partanto, Pius. Kamus IImiah Populer. Surabaya: Arkola,2002.

Syamsi, Hasan. Modern Islamic Parenting Cara Mendidik Anak Masa Kini Dengan Metode Nabi. Aisar Publishing, 2014.

Shihab, Quraisy. Secercah Cahaya Ilahi, Hidup Bersama Al-Qur'an. Bandung: PT Mizan Pustaka, 2007.

Syafe'i, Rahmat. Ilmu Tafsir. Bandung: Pustaka Setia, 2006.

Ummu Ihsan dan Abu Ihsan. Mencetak Generasi Rabbani Mendidik Buah Hati Menggapai Ridha Ilahi. Bogor: CV. Darul IImi, cet II, 2010. 